\title{
Türkiye'de Okulöncesi Eğitimi Yaygınlaştırma Çabaları ve Maliyeti (1990-2002 Dönemi)
}

\section{Efforts to Disseminate and Costs of Preschool Education in Turkey (Years from 1990 to 2002) \\ Gökhan TUZCU*}

- Geliş Tarihi: 19.10.2018 • Kabul Tarihi: 20.06.2019• Yayın Tarihi: 06.07.2019

\begin{abstract}
$\ddot{\mathbf{O z}}$
Bu araştırmada, Türkiye'de okulöncesi eğitimde okul-öğretmen-öğrenci sayıları, okullaşma oranları ve harcamaları çözümlenmiştir. Ayrıca Türkiye'deki gelişmeler ile OECD ülkelerindeki gelişmeler karşılaştırılmıştır. Araştırma, nicel ve betimseldir, tarama modeli ile yapılmıştır, 1990-2002 dönemini kapsamaktadır. Türkiye'deki tüm (kamu+özel) okulöncesi eğitim kurumlarını kapsamaktadır. Araştırmanın bulgularına göre, Türkiye'de okullaşma oranı, öğrenci sayısı, öğretmen sayısı ve okul sayısı her yıl artmış, ancak öğrenci başına yapılan harcama azalmıştır. Bulgular, alanyazınla ilişkilendirilerek tartışılmış ve gelecekte yapılacak araştırmalara yönelik öneriler verilmiştir.
\end{abstract}

Anahtar sözcükler: okulöncesi eğitim, eğitim ekonomisi, eğitim planlamas1.

Atıf:

Tuzcu, G. (2019). Türkiye'de okulöncesi eğitimi yaygınlaştırma çabaları ve maliyeti (1990-2002 dönemi).Pamukkale Üniversitesi Eğitim Fakültesi Dergisi, 47, 88-106. doi: 10.9779/pauefd.472366

\footnotetext{
* Dr. Öğr. Üyesi, Pamukkale Üniversitesi, Eğitim Fakültesi, Denizli, ORCID: 0000-0002-0498-1534, gtuzcu@pau.edu.tr
} 


\begin{abstract}
In this study, number of schools-teachers-students, schooling rates and expenditures in preschool education in Turkey have been analyzed. Besides, the developments in Turkey were compared to the developments in OECD countries. The research is quantitative and descriptive and conducted through "survey research" model. The research covers a period of 13 years (1990-2002). All preschools (state/private) in Turkey included in the study. Findings demonstrated that, schooling rate, number of students and schools in Turkey has increased every year but expenditure per student has decreased. Findings are discussed in relation to the literature and implications for future research are provided.
\end{abstract}

Keywords: preschool education, economics of education, educational planning.

\title{
Cited:
}

Tuzcu, G. (2019). Efforts to disseminate and costs of preschool education in Turkey (years from 1990 to 2002). Pamukkale Üniversitesi Ĕgitim Fakültesi Dergisi, 47, 88-106.doi: 10.9779/pauefd.472366 


\section{Giriş}

Erken çocukluk dönemi (0-6 yaş), çocuğun en hızlı geliştiği dönemdir ve bu dönemdeki deneyimler, beynin çalışma biçimi için belirleyicidir. Alanyazındaki araştırmalar, nitelikli bir okulöncesi eğitim programına katılan çocukların, sosyal, duygusal, sözel, zihinsel ve fiziksel gelişim açısından daha yetkin ve gelecekteki okul başarılarının daha yüksek olduğunu kanıtlamaktadır (AÇEV 2005, s. 7-8; MEB ve UNICEF 2013, s. 12-13).

Bir ülkenin eğitim için harcadığı parasal kaynakların miktarı, o ülkenin genel ekonomisi içinde eğitimin yeri ve önemini göstermektedir. Parasal kaynakların çözümlenmesi, eğitimin hedeflerine ulaşılıp-ulaşılamadığının belirlenmesine ve politikaların daha akılcı oluşturulmasına katk1 sağlamaktadır.

Eğitimcilerin çoğu, eğitim bütçesinin yetersiz olduğunu düşünmektedir. Acaba, bütçedeki artış ile okul-öğretmen-öğrenci sayısındaki artış arasında ilişki var mıdır, varsa ne kadardır? Bu soruyu yanıtlamak için Türkiye'de yapılan araştırma sayısı çok azdır. Yapılan araştırmalar da çoğunlukla anket ve görüşme formu ile toplanan verilere dayanmaktadır. Eğitim sisteminde gerçekleşenleri çözümleyen araştırma sayısı, yok denecek kadar azdır. Hele hele eğitim sisteminde gerçekleşenleri 10-15 yıllık bir süreçte çözümleyen araştırmalara rastlamak neredeyse olanaksızdır.

Okulöncesi eğitimi yaygınlaştırma sürecinde tek sorun bütçenin yetersiz olması mı? Bütçe çok artırılırsa, okul-öğretmen-öğrenci sayısı da çok artacak mı? Bütçe çok artırılırsa, okulöncesi eğitim ülke geneline ve çağ nüfusuna yaygınlaştırılacak mı, yoksa belirli kesimlerde mi kalacak? Okulöncesi eğitimi, ülke geneline ve çağ nüfusuna yaygınlaştırmış olan ülkeler, bunu çok bütçe ile mi yaptılar, yoksa politikalardaki kararlılık ve çalışmalardaki süreklilik ile mi yaptılar?

$\mathrm{Bu}$ araştırma, bu sorulara yanıt arama çabasındadır.

\section{Yöntem}

\section{Araștırmanın Modeli}

Araştırma, tarama modeli ile yapılmıştır, nicel ve betimseldir. Veriler, belge tarama (doküman analizi) ile toplanmıştır. Bilindiği gibi doküman analizi, belgeler üzerinde sistematik olarak derinlemesine yapılan bir araştırmadır. Her türlü belge (kitaplar, dergiler, makaleler, fermanlar, anılar, layihalar, yazıtlar, pullar, flamalar vb) incelenebilir. Bu belgelerdeki veriler, sayısal olarak da saptanabilir. Doküman analizi, hem nicel, hem nitel araştırmalarda kullanılabilir (Sönmez ve Alacapınar, 2011, s. 83 ve 160).

Araştırma, 13 yıllık tarihsel bir süreçte (1990-2002) karşılaştırmalı çözümleme esas alınarak yapılmıştır. Bunun nedeni, geçmişin deneyimlerinden, gelecekteki benzer girişimlerde yararlanılması ve kaynakların savurganca kullanılmasının önlenmesidir. Anılan süreçte OECD ülkelerinde gerçekleşen gelişim ile Türkiye'de gerçekleşen gelişim karşılaştırılmış, aradaki farkl11ıklar ortaya konulmuştur.

Araştırmanın 2002-2003 öğretim yılında son bulmasının nedeni, Türkiye'de bütçe sisteminin 2003 y1lı sonunda değişmesidir (program bütçe sisteminden, analitik bütçe sistemine 
geçilmesidir). $\mathrm{Bu}$ nedenle 2004 ve sonraki yılların eğitim bütçesi farklı tekniklerle çözümlenmek zorundadır.

\section{Araştırmanın Kapsamı}

Türkiye genelinde 3-5 yaş grubundaki çocuklara yönelik tüm okulöncesi eğitim kurumlarına ilişkin incelenmiştir (örneklem alınmamış, evren üzerinde çalışılmıştır). 0-2 yaş grubundaki çocukların yararlandığı kurumlar (kreşler, çocuk yuvaları, oyun grupları vb) araştırma kapsamı dişında tutulmuştur.

Erken çocukluk dönemi 0-6 yaş grubunu kapsamasına karşın, OECD ülkelerinde ve Türkiye'de okulöncesi eğitim çoğunlukla 3-5 yaş grubuna yönelik olduğundan, bu araştırmada da 3-5 yaş grubu incelenmiştir.

Türkiye'ye ilişkin okulöncesi eğitim göstergelerinin karşılaştırıldığı OECD ülkelerinin seçiminde, UNDP 2002 “insani gelişim indeksi” esas alınmıştır. Öncelikle bu indeksteki ilk 20 ülke incelenmiştir. Bunlardan nüfus itibariyle Türkiye'ye benzer olanlar tercih edilmiş, nüfusu çok az olanlar (Norveç, İrlanda, Finlandiya vb) tercih edilmemiştir. İnsani gelişim indeksi ve nüfusun yanı sıra Türkiye'nin $\mathrm{AB}$ üyeliği nedeniyle $\mathrm{AB}$ ülkelerine öncelik tanınmıştır. Seçilen 11 ülkenin coğrafi olarak dünya genelini yansitabileceği düşünülmüştür.

\section{Veri Kaynakları ve Çözümlenmesi}

Araştırma için gereksinim duyulan veriler, ulusal ve uluslararası alanyazın taranarak sağlanmıştır. Milli Eğitim Bakanlığı ve Maliye Bakanlığı’nın "Eğitim Bütçesi Kesin Hesapları”, Milli Eğitim Bakanlığı ve Türkiye İstatistik Kurumu'nun "Milli Eğitim İstatistikleri", OECD'nin "Education Statistics" ve "Education at a Glance-OECD Indicators" isimli kitaplarındaki sayısal veriler kullanılmıştır.

1990-2002 dönemini kapsayan 13 yılda, okul-öğretmen-öğrenci sayılarındaki, okullaşma oranlarındaki ve eğitim harcamalarındaki artışlar/azalışlar "doğrusal (yarı logaritmik) kalıp" ve temel aritmetik yöntemlerle hesaplanmıştır. Böylelikle karşılaştırılabilir veri üretilmiş ve bu veriler çözümlenmiştir. Doğrusal (yarı logaritmik) kalıp $Y=a \cdot b^{x}$ şeklinde formüle edilmekte ve logaritmik olarak artan değişkenin yıllık artış oranları hesaplanırken kullanılmaktadır.

Eğitim harcamaları içinde yer alan, ancak eğitim tür ve düzeyleri itibariyle verilmeyen, genel yönetim, denetim, destek hizmetleri ve programlara dağıtılamayan hizmetlere ilişkin harcamalar, öğrenci sayısı oranında okulöncesi eğitime yansıtılmıştır. İlköğretim ve ortaöğretim okulları içindeki anasınıflarının harcamaları, okulöncesi eğitim düzeyinde gösterilmiştir.

Türk Lirası olarak elde edilen harcama rakamlarını ABD dolarına çevirmede, öğretim yılı ortasındaki (1 Şubat tarihindeki) ABD doları kuru esas alınmıştır.

\section{Bulgular}

Türkiye'de okulöncesi eğitim çağ nüfusu, okullaşma oranı, öğrenci-öğretmen-okul sayıları çözümlenmiş ve bu göstergeler ile harcamalar karşılaştırılmıştır. 


\section{Okulöncesi Eğitim Çağ Nüfusu}

Türkiye'de olduğu gibi OECD ülkelerinin çoğunda da okulöncesi eğitim 3-5 yaş grubundaki çocuklara yöneliktir. Diğer bir deyişle çocuklar ilk kez üç/dört yaşlarında eğitime başlamaktadır ve okulöncesi eğitimin süresi ortalama üç yıldır (EURYDICE/EACEA, 2009, s.22-30).

Dengeli ve sürdürülebilir kalkınma ile uyumlu nüfus yapısına ulaşmak, ancak nüfusun eğitim niteliklerinin iyileştirilmesi ve yaşam kalitesinin yükseltilmesiyle sağlanabilir (DPT 2000, s.79). Türkiye'de okulöncesi eğitim çağındaki (3-5 yaş) çocuk nüfusun 1990-2002 dönemindeki gelişimi Tablo 1'de görülmektedir.

Tablo 1. Türkiye'de 3-5 Yaş Grubundaki Nüfusun Gelişimi

\begin{tabular}{|c|c|c|c|}
\hline & $\mathrm{Klz}$ & Erkek & Toplam \\
\hline 1990 & 2.009 .967 & $\begin{array}{c}2.116 \\
.435\end{array}$ & 4.126 .402 \\
\hline 2002 & 2.039 .094 & $\begin{array}{c}2.172 \\
.860\end{array}$ & 4.211 .954 \\
\hline Yıllık Artış Hızı (\%o) & 1,2 & 2,2 & 1,7 \\
\hline
\end{tabular}

Kaynak: TÜİK (DİE), 1990 ve 2000 Genel Nüfus Sayımları ve Nüfus Projeksiyonları.

Türkiye'de 1990-2002 döneminde okulöncesi eğitim çağındaki çocuk sayısı 86 bin dolayında (\% 2,1) artmıştır. Yıllık ortalama artış 7 bin dolayındadır. Türkiye'de okulöncesi eğitim çağındaki çocuk sayısı, bazı AB ülkelerinin (Danimarka, Finlandiya, İrlanda, Norveç) toplam nüfusuna hemen hemen eşittir. Bu bağlamda, Türkiye'nin okulöncesi eğitim için harcayacağı kaynakların yüksek olduğu ortaya çıkmaktadır.

1990-2002 döneminde Türkiye'nin toplam nüfusu yılda ortalama \%o 16,0 hızla artmış, okulöncesi eğitim çağındaki nüfusu ise \%o 1,7 hızla artmıştır. Diğer bir deyişle, toplam nüfusa göre çocuk nüfusun artış hızı oldukça düşüktür ve giderek daha da düşmektedir. Türkiye'de çocuk nüfusu, hemen hemen hiç artmamaktadır.

Gelişmiş OECD ülkelerinde kadın başına ortalama çocuk sayısı 1990 yılında 1,9 iken 2002 yllında 1,5'dir. Türkiye'de ise 1990 yılında 2,9 iken 2002 yılında 2,5'tir (OECD 2005, s.10-11). Diğer bir deyişle, OECD ülkelerinde olduğu gibi Türkiye'de de kadın başına çocuk sayısı düşmüştür. Ancak OECD ülkelerinde düşme eğilimi sona ermiştir ve 1,5 dolayında seyretmektedir. Türkiye'de ise bir süre daha düşeceği öngörülmektedir.

\section{Okulöncesi Eğitim Öğrenci Sayısı}

Okulöncesi eğitimin (ISCED 0) gelişmesi için, Türkiye'de kamu sektörü, özel sektör ve sivil toplum örgütleri tarafindan birçok çalışma yürütülmektedir. Son y1llarda gerek ulusal, gerek yerel çevreyi bilinçlendirmeye ve böylece okulöncesi eğitimi yaygınlaştırmaya yönelik çalışmalar hızlandırılmıştır. Türkiye'de 1990-2002 döneminde okulöncesi eğitim öğrenci sayısındaki artış Tablo 2'de görülmektedir. 
Tablo 2. Türkiye'de Okulöncesi Eğitim Öğrenci Sayısı (Kamu+Özel)

\begin{tabular}{|c|c|c|c|c|}
\hline Öğretim Y1lı & Kiz & Erkek & Toplam & Bir Önceki Yıla Göre Artış \\
\hline 1990-1991 & 56.641 & 63.225 & 119.866 & 7.813 \\
\hline $1992-1993$ & 64.506 & 71.611 & 136.117 & 3.152 \\
\hline 1994-1995 & 70.350 & 77.738 & 148.088 & 4.739 \\
\hline 1996-1997 & 82.038 & 92.672 & 174.710 & 16.356 \\
\hline 1998-1999 & 96.526 & 107.935 & 204.461 & 21.928 \\
\hline $2000-2001$ & 107.643 & 119.821 & 227.464 & 14.861 \\
\hline $2002-2003$ & 135.091 & 148.214 & 283.305 & 29.792 \\
\hline
\end{tabular}

Kaynak: TÜİK (DİE), Milli Eğitim İstatistikleri (1990-2002).

1990-2002 döneminde okulöncesi eğitim öğrenci sayıs1 119.866'dan 283.305'e yükselmiştir. Diğer bir deyişle, öğrenci sayısı her yıl ortalama \% 7,1 artmıştır. Bu dönemde okulöncesi eğitimde yer alan çocukların artışı, kız ve erkek öğrencilerde hemen hemen aynıdır, aralarında belirgin bir farklılık yoktur. Bu durum, eğitimdeki cinsiyet ayrımcıllı̆ının ileriki y1llarda son bulabileceğine ilişkin bir gösterge olarak görülebilir.

Türkiye'de araştırmanın kapsadığı yıllarda, okulöncesi eğitime yönelik toplumsal istem her geçen yıl artmıştır. Örneğin, bir önceki yıla göre 1990 yılında öğrenci sayısı 7.813 artmışken, 2002 yılında 29.792 artmıştır. Bu artış doğal olarak, bina, donanım, öğretmen ve bütçe artışını da beraberinde getirmektedir. Aynı zamanda ailelerin giderek bilinçlendiğini, çocuk sayısından çok, çocuğun niteliğine önem verdiklerini göstermektedir.

Türkiye'de 1990-2002 döneminde okulöncesi eğitim öğrenci sayısının köy-şehir ayrımında artışı Tablo 3 'te görülmektedir.

Tablo 3. Türkiye'de Okulöncesi Eğitim Öğrenci Sayısı (Kamu+Özel)

\begin{tabular}{|c|c|c|c|c|}
\hline Öğretim Y1l1 & Köy & Şehir & Toplam & Bir Önceki Yıla Göre Artış \\
\hline 1990-1991 & 15.012 & 104.854 & 119.866 & 7.813 \\
\hline 1992-1993 & 20.069 & 116.048 & 136.117 & 3.152 \\
\hline 1994-1995 & 18.894 & 129.194 & 148.088 & 4.739 \\
\hline 1996-1997 & 21.976 & 152.734 & 174.710 & 16.356 \\
\hline 1998-1999 & 24.302 & 180.159 & 204.461 & 21.928 \\
\hline 2000-2001 & 25.697 & 201.767 & 227.464 & 14.861 \\
\hline $2002-2003$ & 55.925 & 227.380 & 283.305 & 29.792 \\
\hline
\end{tabular}

Kaynak: TÜİK (DİE), Milli Eğitim İstatistikleri (1990-2002).

1990-2002 döneminde köylerdeki (kırsal kesimdeki) öğrenci sayısı, yılda ortalama \% 7,7 artışla 15.012 'den 55.925'e yükselmiştir. Anılan dönemde şehirlerdeki öğrenci sayısı ise yılda ortalama \% 6,9 artışla 104.854'den 227.380 'e yükselmiştir. Görüldüğü gibi köylerdeki artış, şehirlerden daha yüksek olmuştur. Bu bağlamda, eğitimde firsat ve olanak eşitliğinin sağlanmasına yönelik çalışmaların yoğunlaştırıldığı söylenebilir.

Bu bağlamda gözden kaçırılmaması gereken konu, Türkiye'de köylerin oldukça dağınık bir yapıda oluşudur. Bu dağınık yapı, eğitim hizmetlerinin zamanında ve nitelikli ulaştırılmasını engellediği gibi, maliyetleri de artırmaktadır.

Gelişmiş OECD ülkelerinde, 1990-2002 döneminde okulöncesi eğitim öğrenci sayısındaki artış Tablo 4'te görülmektedir. 
Tablo 4. OECD Ülkelerinde Okulöncesi Eğitim Öğrenci Sayısı (Kamu+Özel)

\begin{tabular}{|c|c|c|c|}
\hline Ülke & 1990-1991 Öğr. Ylll & 2002-2003 Öğr. Ylll & Artış Oranı (\%) \\
\hline Almanya & 1.727 .512 & 2.316 .687 & 34,1 \\
\hline Fransa & 2.535 .955 & 2.466 .267 & $-2,7$ \\
\hline İngiltere & 775.830 & 1.083 .589 & 39,7 \\
\hline İtalya & 1.566 .364 & 1.623 .229 & 3,6 \\
\hline İsveç & 92.900 & 320.967 & 245,5 \\
\hline İsviçre & 136.845 & 155.879 & 13,9 \\
\hline Avustralya & vy & 258.529 & - \\
\hline Kanada & 237.500 & 470.234 & 98,0 \\
\hline $\mathrm{ABD}$ & 4.635 .272 & 7.242 .728 & 56,3 \\
\hline Japonya & 2.039 .556 & 3.047 .169 & 49,4 \\
\hline G.Kore & vy & 548.050 & - \\
\hline Ortalama & 1.527 .526 & 1.775 .757 & 16,3 \\
\hline Türkiye & 119.866 & 283.305 & 136,4 \\
\hline
\end{tabular}

http://stats.oecd.org/wbos/Index.aspx?DatasetCode=RENRL. vy: Veri yok.

Okulöncesi eğitimdeki öğrenci sayısı, OECD ülkelerinde \% 16,3; Türkiye'de ise \% 136,4 artmıştır. Her ne kadar öğrenci sayısı hızlı artıyor olsa da Türkiye, OECD ülkelerinden oldukça geridedir. Okulöncesi eğitime önem verme ve yaygınlaştırma konusunda Türkiye, oldukça geç kalmıştır. Örneğin, 2002-2003 öğretim y1lında bir OECD ülkesindeki ortalama öğrenci sayısı, Türkiye'deki öğrenci sayısının 6 katıdır. Nüfusu Türkiye'nin nüfusuna yakın olan Almanya, Fransa ve İtalya'da öğrenci sayısı, Türkiye'deki öğrenci sayısının ortalama 8 katıdır. Nitekim, OECD ülkelerinde 2004 yılında tüm örgün eğitim öğrencilerinin \% 10'unu okulöncesindeki öğrenciler oluştururken, Türkiye'de ancak \% 2'sini oluşturmaktadır (www.oecd.org/edu/eag2005).

\section{Okulöncesi Eğitim Okullaşma Oranı}

Okullaşma oranı, herhangi bir yılda okulöncesi eğitimdeki öğrencilerin, o yılda okulöncesi eğitim çağındaki tüm nüfusa bölünmesiyle elde edilmektedir. Türkiye'de 1990-2002 döneminde okulöncesi eğitim okullaşma oranındaki artış Tablo 5'te görülmektedir.

Tablo 5. Türkiye'de Okulöncesi Eğitim Okullaşma Oranı (\%, Brüt)

\begin{tabular}{|c|c|c|c|}
\hline Öğretim Y1lı & Kiz & Erkek & Toplam \\
\hline 1990-1991 & 2,8 & 3,0 & 2,9 \\
\hline $1992-1993$ & 3,2 & 3,4 & 3,3 \\
\hline 1994-1995 & 3,5 & 3,7 & 3,6 \\
\hline 1996-1997 & 4,1 & 4,4 & 4,2 \\
\hline 1998-1999 & 4,8 & 5,1 & 4,9 \\
\hline $2000-2001$ & 5,4 & 5,6 & 5,5 \\
\hline 2002-2003 & 6,6 & 6,8 & 6,7 \\
\hline
\end{tabular}

Kaynak: TÜİK (DİE), Milli Eğitim İstatistikleri (1990-2002) ve Nüfus Projeksiyonları.

1990-2002 döneminde öğrenci sayısının 163.439 artması, okullaşma oranlarını da artırmıştır. Nitekim 1990-1991 öğretim yılında okullaşma oranı \% 2,9 iken, 2002-2003 öğretim 
yılında \% 6,7'ye yükselmiştir. Diğer bir deyişle okullaşma oranı yılda ortalama $\% 0,3$ artmıştır. $\mathrm{Bu}$ artış, yok denecek kadar azdır. Her ne kadar artış olsa da, Türkiye'de okullaşma oranının en düşük olduğu eğitim düzeyi, okulöncesi eğitimdir. Çok düşük düzeyde olan okullaşma oranı, bu alana hızlı bir biçimde yatırım yapılması gerektiğini göstermektedir.

Kız ve erkek öğrencilerin okullaşma oranları arasında belirgin bir farklılık yoktur. $\mathrm{Bu}$ durum, çocuğunu okulöncesi eğitime gönderen ailelerin bilinçli olmasına, devletin de okulöncesi eğitimi yaygınlaştırma çabasında olmasına bağlanabilir. Doğal olarak fırsat ve olanak eşitliğinde bir artış da sağlanmaktadır.

Gelişmiş OECD ülkelerinde okulöncesi eğitimdeki okullaşma oranı Tablo 6'da görülmektedir.

1990-2002 döneminde okullaşma oranı, gelişmiş OECD ülkelerinde \% 66,5'ten \% 86,9'a, Türkiye'de ise \% 2,9'dan \% 6,7'ye yükselmiştir. Diğer bir deyişle okullaşma oranındaki artış, OECD ülkelerinde ortalama 20,5 iken, Türkiye'de 3,8'dir. Türkiye'deki artış oranının önümüzdeki yıllarda da aynen sürmesi durumunda Türkiye, OECD ülkelerinin 2002 yılı okullaşma oranına (\% 86,9) ancak 2040 y1lında ulaşabilecektir. 2002-2003 öğretim yılında OECD ülkelerindeki okullaşma oranı, Türkiye'dekinin 13 katıdır.

Tablo 6. OECD Ülkelerinde Okulöncesi Eğitim Okullaşma Oranı (\%, Brüt)

\begin{tabular}{|c|c|c|c|}
\hline Ülke & 1990-1991 Öğr. Yılı & 2002-2003 Öğr. Yllı & Fark (Artış) \\
\hline Almanya & 80,0 & 99,6 & 19,6 \\
\hline Fransa & 83,3 & 100,0 & 16,7 \\
\hline İngiltere & 52,4 & 77,7 & 25,3 \\
\hline İtalya & 93,4 & 100,0 & 6,6 \\
\hline İsveç & 64,7 & 81,1 & 16,4 \\
\hline İsviçre & 59,7 & 99,7 & 40,0 \\
\hline Avustralya & 71,3 & 100,0 & 28,7 \\
\hline Kanada & 60,4 & 64,6 & 4,2 \\
\hline ABD & 62,6 & 62,9 & 0,3 \\
\hline Japonya & 48,1 & 84,9 & 36,8 \\
\hline G.Kore & 55,4 & 85,8 & 30,4 \\
\hline Ortalama & 66,5 & 86,9 & 20,5 \\
\hline Türkiye & 2,9 & 6,7 & 3,8 \\
\hline
\end{tabular}

Kaynak: UNESCO, Global Monitoring Report 2002, s.222-226 ve 2006, s.296-303; Education for All 2007, s.250 (www.unesco.org).

\section{Okulöncesi Eğitim Öğretmen Sayısı}

Türkiye'de okulöncesi eğitim öğretmeni yetiştirme çalışmaları 1960 yılında başlamıştır (www.ooegm.meb.gov.tr/22tarihce.asp). 1960 öncesinde okulöncesi eğitim, çoğunlukla ilköğretim öğretmenlerince yürütülmüştür. İnsan yaşamında en temel niteliklerin kazanıldığ süreç olması nedeniyle çok ayrı bir öneme sahip olan okulöncesi eğitim dönemi, doğal olarak nitelikli öğretmen gerektirmektedir.

Türkiye'de okulöncesi eğitim öğretmeni sayısındaki artış Tablo 7'de görülmektedir. Türkiye'de 1990-2002 döneminde öğretmen sayısı 7.124'ten 13.356'ya yükselmiştir. Diğer bir 
deyişle yılda ortalama \% 5,2 artmıştır. Bazı yıllarda azalma olması, okulöncesi eğitimden ayrılıp ilköğretime geçen öğretmenlerden kaynaklanmaktadır.

Tablo 7. Türkiye'de Okulöncesi Eğitim Öğretmeni Sayısı (Kamu+Özel)

\begin{tabular}{|c|c|c|c|c|}
\hline Öğretim Y1lı & Kadın & Erkek & Toplam & Bir Önceki Yıla Göre Artış \\
\hline $1990-1991$ & 7.095 & 29 & 7.124 & -120 \\
\hline $1992-1993$ & 8.372 & 28 & 8.400 & 405 \\
\hline 1994-1995 & 9.049 & 49 & 9.098 & 190 \\
\hline 1996-1997 & 9.930 & 41 & 9.971 & 200 \\
\hline 1998-1999 & 10.912 & 67 & 10.979 & 603 \\
\hline $2000-2001$ & 11.730 & 166 & 11.896 & 305 \\
\hline $2002-2003$ & 12.878 & 478 & 13.356 & -939 \\
\hline
\end{tabular}

Kaynak: TÜi̇K (DİE), Milli Eğitim İstatistikleri (1990-2002).

1990 y1lında öğretmenlerin hemen hemen \% 100'ü kadın iken, 2002 yılında \% 96's1 kadındır. OECD ülkelerinde de öğretmenlerin \% 96'sı kadındır. Diğer bir deyişle, dünya genelinde okulöncesi eğitim öğretmenliği, kadın mesleği olarak kabul edilmektedir.

Türkiye'de 1990-1991 öğretim yılında öğretmen başına ortalama 17 öğrenci düşerken, 2002-2003 öğretim yılında 21 öğrenci düşmektedir. Diğer bir deyişle, öğrenci artışına paralel olarak öğretmen görevlendirilmemiştir. Ayrıca Türkiye'de öğretmen başına 21 öğrenci düşerken, OECD ülkelerinde 15 öğrencinin düştüğü göz önüne alındığında, Türkiye'nin öğretmen görevlendirmeyi hızla artırması gerekecektir. Bu da okulöncesi eğitim harcamalarının hızla artması anlamına gelecektir.

\section{Okulöncesi Eğitim Okul Sayısı}

Türkiye'de okulöncesi eğitim kurumları; bağımsız anaokulları ile ilköğretim ve ortaöğretim okulları içindeki anasınıflarından oluşmaktadır. Türkiye Cumhuriyeti'nin kurulduğu 1923 yılında 80 anaokulu, 136 öğretmen ve 5.880 öğrenci vardı (www.ooegm.meb.gov.tr/22tarihce.asp). Türkiye'de 1990-2002 döneminde okulöncesi eğitim okulu/sınıfı sayısındaki artış Tablo 8'de görülmektedir.

Tablo 8. Türkiye'de Okulöncesi Eğitim Okul/Sınıf Sayısı (Kamu+Özel)

\begin{tabular}{|c|c|c|c|c|}
\hline Öğretim Y1lı & Köy & Şehir & Toplam & Bir Önceki Yıla Göre Artış \\
\hline 1990-1991 & 837 & 2.969 & 3.806 & 205 \\
\hline $1992-1993$ & 1.175 & 3.508 & 4.683 & 218 \\
\hline 1994-1995 & 1.171 & 3.998 & 5.169 & 261 \\
\hline 1996-1997 & 1.408 & 4.674 & 6.082 & 482 \\
\hline 1998-1999 & 1.560 & 5.308 & 6.868 & 305 \\
\hline $2000-2001$ & 1.834 & 6.421 & 8.255 & 595 \\
\hline 2002-2003 & 3.767 & 7.106 & 10.873 & 1.393 \\
\hline
\end{tabular}

Kaynak: TÜİK (DİE), Milli Eğitim İstatistikleri (1990-2002).

Türkiye'de 1990-2002 döneminde okul/sınıf sayısı 3.806'dan 10.873'e yükselmiştir. Diğer bir deyişle okul/sınıf sayısı yılda ortalama \% 8,2 artmıştır. Bu artışın, toplumsal ve ekonomik kalkınmanın nitelikli insangücüyle sağlanabileceği, nitelikli insangücünün de ancak eğitimle yetiştirilebileceği anlayışından kaynaklandığı söylenebilir. Ancak 10.873 okulun \% 15'i anaokulu, \% 85'i ilköğretim ve ortaöğretim okulları içindeki anasınıflarıdır. Diğer bir 
deyişle, Türkiye'de bağımsız anaokulları yerine, ilköğretim ve ortaöğretim okulları içinde anasınıfları yaygınlaştırılmıştır.

1990-1991 öğretim yılında okulların/sınıfların \% 22'si köylerde, \% 78'i şehirlerdedir. 2002-2003 öğretim y1lında ise \% 35'i köylerde, \% 65'i şehirlerdedir. Diğer bir deyişle Türkiye'de okulöncesi eğitimin köylerde (kırsal kesimde) de yaygınlaştırılması için çaba harcanmıştır. Bunun, ülke genelinde firsat ve olanak eşitliğinin sağlanmasına yönelik bir anlayıştan kaynaklandığı söylenebilir. Anılan dönemde okulöncesi eğitim okulları/sınıfları köylerde yılda ortalama \% 9,7 artmışken, şehirlerde \% 7,6 artmıştır.

Nüfusun çok dağınık ve az yoğun bir yerleşim düzeni içinde bulunması, büyük eğitimsel çabaları gerektirmektedir. Çünkü nüfusu çok az ya da çok fazla olsun, tüm yerleşim birimlerindeki yurttaşlara eğitim sunulmak zorundadır. Ancak, nüfusun ülke düzeyine dăğlımı, eğitimin daha kolay ya da daha zor sunulmasına neden olmaktadır. Bu durum, şehirlerde giderek artan eğitim isteminin karşılanması için çözüm önerilerinin oluşturulmasını, diğer yandan köylerdeki nüfusun da ihmal edilmemesi gerektiğini göstermektedir.

\section{Okulöncesi Eğitim Harcamaları}

Okulöncesi eğitim için harcanan kaynakların çözümlenmesi, okulöncesi eğitimin planlanmasına ve kaynakların daha akılcı kullanılmasına katkıda bulunur.

Türkiye'de olduğu gibi OECD ülkelerinde de eğitim, çoğunlukla kamu kaynaklarıyla finanse edilmekte ve çeşitli araştırmalar da eğitim için harcanan kaynakların, boşa harcanmadığını göstermektedir. Bir yıllık ek eğitimin, ekonomik çıktılar üzerindeki uzun dönemde etkisi, genel olarak \% 3 ile $\% 6$ arasındadır. Kişi başına düşen ulusal gelirin en az yarısı, işgücü verimliliğindeki artıştan kaynaklanmaktadır (OECD 2006, s.27). Bu bağlamda Türkiye'de okulöncesi eğitime yapılan kamu harcamaları ve tüm kamu eğitim harcamaları içindeki oranının 1990-2002 dönemindeki durumu Tablo 9'da görülmektedir.

Tablo 9. Türkiye'de Okulöncesi Eğitim Harcamaları ve Tüm Kamu Eğitim Harcamaları İçindeki Oranı

\begin{tabular}{|c|c|c|c|}
\hline Öğretim Yilı & $T L$ & $A B D \$$ & Kamu İçinde \% \\
\hline 1990-1991 & 191.320 .172 .711 & 63.079 .516 & 0,8 \\
\hline $1992-1993$ & 788.445 .881 .382 & 88.689 .076 & 1,0 \\
\hline 1994-1995 & 2.121 .710 .932 .507 & 52.258 .890 & 1,0 \\
\hline 1996-1997 & 11.888.166.136.670 & 102.927 .845 & 1,2 \\
\hline 1998-1999 & 39.535.099.313.332 & 118.724 .022 & 1,2 \\
\hline 2000-2001 & 81.833.303.573.973 & 121.234 .524 & 1,2 \\
\hline $2002-2003$ & 214.523.626.255.503 & 131.367 .805 & 1,5 \\
\hline Ortalama & -- & 118.946 .980 & 1,2 \\
\hline
\end{tabular}

Kaynak: Maliye Bakanlığı, Bütçe Kesin Hesap Yasa Tasarıları (MEB+YÖK) ve DPT, Ekonomik ve Sosyal Göstergeler (1950-2006), s.188.

1990-2002 döneminde okulöncesi eğitim harcamaları 63 milyon \$ dolayından 131 milyon \$ dolayına yükselmiştir. Yıllık ortalama artış oranı \% 6,1'dir.

Türkiye'de okulöncesi eğitim harcamaları 1994 ve 1995 yıllarında, bir önceki yıla oranla Türk Lirası bazında \% 30, ABD doları bazında \% 40 azalmıştır. Oysa anılan yıllarda öğrenci sayısı bir önceki yıla oranla ortalama \% 4 artmıştır. Öğrenci sayısı \% 4 artarken, 
harcamaların \% 30-40 azalması; eğitimcilerin satınalma gücünün düştüğünü, ders araç-gereçleri, okul donanımı, sosyal etkinlikler vb olanakların azaldığını ve yatırımların tamamlanma sürelerinin uzadığını göstermektedir. Bu olumsuz tablo 1994, 1999, 2001 ekonomik krizleri dönemlerinde yaşanmıştır. Harcamalar bu dönemlerde belirgin bir biçimde düşmüştür. Yaşanan krizlerin yanı sıra, artan nüfus, artan üniversite sayısı, sekiz yıllık ilköğretime geçiş gibi olaylar nedeniyle okulöncesi eğitim harcamalarında düşüşler olmuştur.

1990-1991 öğretim yılında tüm kamu eğitim harcamalarının \% 0,8'i okulöncesi eğitim için harcanmışken, 2002-2003 öğretim yılında \% 1,5’i harcanmıştır. Okulöncesi eğitim harcamalarının, tüm eğitim harcamaları içindeki oranı, 1990'dan 2002'ye sürekli ve düzenli artmıştır. Ancak Türkiye'de öğrenci sayısı en az olan okulöncesi eğitim, harcamalarda da en az düzeydedir.

\section{Okulöncesi Eğitimde Öğrenci Başına Harcama}

Bir öğrenci için yapılan yıllık harcamanın çözümlenmesi; toplum olarak katlanılan çabayı gösterirken, diğer yandan da eğitim sistemini ekonomik olarak çözümlemenin bir boyutunu oluşturur. Türkiye'de okulöncesi eğitimde öğrenci başına yapılan yıllık ortalama harcamalar, Türk Lirası (TL) ve ABD Doları (\$) cinsinden Tablo 10'da görülmektedir.

Tablo 10. Türkiye'de Okulöncesi Eğitimde Öğrenci Başına Ortalama Harcama (Kamu)

\begin{tabular}{|c|c|c|}
\hline Öğretim Yill & TL & $\$$ \\
\hline 1990-1991 & 1.562 .499 & 515 \\
\hline $1992-1993$ & 5.070 .458 & 570 \\
\hline 1994-1995 & 12.126 .707 & 299 \\
\hline 1996-1997 & 49.657 .403 & 430 \\
\hline 1998-1999 & 167.651 .808 & 503 \\
\hline $2000-2001$ & 329.786 .317 & 489 \\
\hline $2002-2003$ & 665.326 .484 & 407 \\
\hline Ortalama & -- & 459 \\
\hline
\end{tabular}

Kaynak: MEB Bütçe Kesin Hesapları ve TÜíK (DİE) Millî Eğitim İstatistikleri kullanılarak, yazar tarafindan hesaplanmıştır.

Türkiye'de 1990-2002 döneminde öğrenci başına yılda ortalama 459 \$ harcama yapılmıştır. Dönem başında öğrenci başına ortalama 515 \$ harcama yapılmışken, dönem sonunda 407 \$'a düşmüştür. Bu düşüş \% 21 dolayındadır. Oysa öğrenci sayısı her yıl ortalama \% 7,1 artmıştır. Harcamalar, özellikle ekonomik krizlerin yaşandığı yıllarda azalmıştır.

Öğrenci başına yapılan harcama (ABD \$), her yıl ortalama \% 1,3 azalmış, öğrenci sayısı ise her yıl ortalama \% 7,1 artmıştır. Diğer bir deyişle, öğrenci artışına paralel harcama yapılmamıştır. $\mathrm{Bu}$ durum, eğitim finansman ve harcama planlamasının, bilimsel veriler esas alınarak yapılmadığını göstermektedir. Öğrenci sayısındaki artışın yanı sıra, okulların, çocukların bilişsel, duyuşsal ve devinişsel gelişimlerini destekleyecek çok yönlü çağdaş eğitim ortamları haline getirilemediğinin de bir göstergesi olarak kabul edilebilir.

Gelişmiş OECD ülkelerinde öğrenci başına yapılan yıllık ortalama harcamanın 19901991 öğretim yılından 2002-2003 öğretim yılına kadar olan gelişimi Tablo 11'de görülmektedir. 
Tablo 11. Okulöncesi Eğitimde Öğrenci Başına Harcama (ABD \$)

\begin{tabular}{|c|c|c|c|c|}
\hline \multirow{2}{*}{ Ülke } & \multicolumn{2}{|c|}{ Кати } & \multicolumn{2}{|c|}{ Kamu+Özel } \\
\hline & 1990-1991 & $2002-2003$ & 1990-1991 & $2002-2003$ \\
\hline Almanya & - & 4.865 & 1.517 & 4.865 \\
\hline Fransa & 2.163 & 4.744 & 2.506 & 4.744 \\
\hline İngiltere & 2.233 & 7.153 & 4.566 & 7.153 \\
\hline İtalya & - & 6.116 & - & \\
\hline İsveç & 2.501 & 4.091 & 2.501 & 4.091 \\
\hline İsviçre & 2.017 & 3.558 & - & \\
\hline Avustralya & - & - & - & - \\
\hline Kanada & - & - & 4.535 & - \\
\hline ABD & 4.014 & 7.755 & 3.088 & 7.755 \\
\hline Japonya & - & 3.766 & 1.962 & 3.766 \\
\hline G.Kore & - & 2.628 & - & 2.628 \\
\hline Ortalama & 2.586 & 4.964 & 2.954 & 5.000 \\
\hline Türkiye & 515 & 407 & $863^{1}$ & $1.107^{1}$ \\
\hline
\end{tabular}

Kaynak: OECD, Education at a Glance, 1993-s.92; 1998-s.119; 2006 (www.oecd.org/edu/eag2006); OECD Education Database ve Türkiye için Tuzcu (2006), s.191. 1: TÜİK 2002 Araştırmasındaki oran kullanılarak hesaplanmıştır.

OECD ülkelerinde hem kamu, hem özel sektör okullarında yapılan harcama her yıl artmıştır. Türkiye'de ise yalnızca özel sektör okullarında artmıştır. Nitekim 1990-2002 döneminde kamu kaynaklarından yapılan öğrenci başına harcama, OECD ülkelerinde 2.586 \$'dan 4.964 \$'a yükselmiş, Türkiye'de ise 515 \$'dan 407 \$'a düşmüştür. Diğger bir deyişle 13 y1llık süreçte öğrenci başına kamu harcaması OECD ülkelerinde \% 92 artarken, Türkiye'de \% 21 azalmıştır. Kamu ve özel okullardaki öğrenciler bir bütün olarak değerlendirildiğinde, öğrenci başına harcama OECD ülkelerinde 2.954 \$'dan 5.000 \$'a yükselmiş, Türkiye'de ise 863 \$'dan 1.107 \$'a yükselmiştir. Diğer bir deyişle OECD ülkelerinde yapılan harcama \% 69 artarken, Türkiye'de \% 28 artmıştır. OECD ülkelerinde yapılan harcama (kamu+özel) 1990 yılında Türkiye'dekinden 3,4 kat fazla iken, 2002 yılında 4,5 kat fazladır. Türkiye'deki artışın, özel sektöre ait okullardan kaynaklandığı da unutulmamalıdır.

OECD ülkelerinde okulöncesi eğitimdeki öğrencilerin ve harcamaların, eğitim sistemindeki tüm örgün öğrenciler ve tüm eğitim harcamaları içindeki oranı Tablo 12 'de görülmektedir.

1990-2002 döneminde OECD ülkelerinde okulöncesi eğitim öğrencilerinin, tüm örgün eğitim öğrencileri içindeki oranı \% 11,1'den \% 9,4'e düşerken; tüm eğitim harcamaları içindeki oranı \% 5,0'dan \% 6,1'e yükselmiştir. Diğer bir deyişle harcama miktarındaki artış, öğrenci sayısındaki artıştan fazla olmuştur. Bu da, OECD ülkelerinin okulöncesi eğitime nitel ve nicel anlamda giderek daha çok önem verdiğini göstermektedir. Anılan dönemde Türkiye'de öğrenci/harcama oranı, gerek 1990-1991 öğretim y1lında, gerek 2002-2003 öğretim yılında 1.4 'tür, herhangi bir artış görülmemiştir.

OECD ülkelerinde tüm örgün eğitim öğrencileri içinde okulöncesi eğitim öğrencilerinin oranı, Türkiye'deki oranın 4,7 katıdır. Tüm eğitim harcamaları içinde okulöncesi eğitim harcamalarının oranı ise, Türkiye'deki oranın 4,4 katıdır. 
Tablo 12. Okulöncesi Eğitimdeki Öğrencilerin ve Harcamaların, Eğitim Sistemindeki Tüm Örgün Öğrenciler ve Harcamalar İçindeki Oranı (\%)

\begin{tabular}{|c|c|c|c|c|}
\hline \multirow{2}{*}{ Ülke } & \multicolumn{2}{|c|}{ 1990-1991 Öğr. Ylll } & \multicolumn{2}{|c|}{ 2002-2003 Öğr. Ylll } \\
\hline & Ögrenci & Harcama & Öğrenci & Harcama \\
\hline Almanya & 14,6 & 4,4 & 13,6 & 9,7 \\
\hline Fransa & 18,1 & 10,4 & 17,1 & 11,1 \\
\hline İngiltere $^{1}$ & 6,9 & 3,9 & 6,2 & 6,1 \\
\hline İtalya & - & - & $11,5^{1}$ & 9,1 \\
\hline İsveç & 6,4 & 2,6 & 14,6 & 7,4 \\
\hline İsviçre $^{1}$ & 11,2 & 3,5 & $10,8^{1}$ & 3,8 \\
\hline Avustralya & - & - & 2,8 & 1,7 \\
\hline Kanada & - & - & $4,9^{1}$ & - \\
\hline ABD & 12,4 & 5,8 & 8,4 & 5,6 \\
\hline Japonya & 8,0 & 4,2 & 8,3 & 3,9 \\
\hline G.Kore & - & - & 4,7 & 2,1 \\
\hline Ortalama & 11,1 & 5,0 & 9,4 & 6,1 \\
\hline Türkiye & 1,1 & $0,8^{1}$ & 2,0 & $1,4^{1}$ \\
\hline
\end{tabular}

Kaynak: OECD, Education at a Glance, 1993-s.73 ve 2006-s.220 (www.oecd.org/edu/eag2006) ve Türkiye için Tuzcu (2006), s.97 ve 191. 1: Kamu.

\section{Okulöncesi Eğitim Harcamalarının Dağılımı}

Türkiye'de kamu kesimine (devlete) ait okulöncesi eğitim harcamalarının türlere göre dağılımı Tablo 13'te görülmektedir.

Tablo 13. Türkiye'de Okulöncesi Eğitim Harcamaları (Kamu, ABD \$)

\begin{tabular}{|c|c|c|c|c|}
\hline Öğretim Yılı & Cari & Yatırım & Transfer & Toplam \\
\hline 1990-1991 & 56.413 .429 & 4.821 .940 & 1.844 .147 & 63.079 .516 \\
\hline $1992-1993$ & 72.092 .208 & 14.534 .906 & 2.061 .961 & 88.689 .076 \\
\hline 1994-1995 & 41.640 .590 & 10.066 .611 & 551.689 & 52.258 .890 \\
\hline 1996-1997 & 69.829 .967 & 32.213 .983 & 883.896 & 102.927 .845 \\
\hline 1998-1999 & 95.608 .557 & 21.987.922 & 1.127 .544 & 118.724 .022 \\
\hline $2000-2001$ & 102.526 .781 & 17.524 .300 & 1.183 .442 & 121.234 .524 \\
\hline $2002-2003$ & 111.040 .973 & 19.918 .082 & 408.751 & 131.367 .805 \\
\hline Ortalama & $\% 80,4$ & $\% 18,4$ & $\% 1,2$ & $\% 100,0$ \\
\hline
\end{tabular}

Kaynak: MEB Bütçe Kesin Hesapları ve TÜiK (DİE) Millî Eğitim İstatistikleri kullanılarak, yazar tarafından hesaplanmıştır.

Türkiye'de okulöncesi eğitim harcamalarının ortalama olarak \% 80,4'ünü cari, \% 18,4'ünü yatırım ve \% 1,2'sini de transfer harcamaları oluşturmaktadır. OECD ülkelerinde olduğu gibi Türkiye'de de eğitim personeli ve okul malzemeleri için yapılan cari harcamalar, en büyük harcama türünü oluşturmaktadır. 1990-2002 döneminde cari harcamalar 56 milyon \$ dolayından 111 milyon \$ dolayına yükselmiş̧ir. Yılda ortalama \% 5,8 artmıştır.

1990-2002 döneminde okulöncesi eğitimde yatırım harcamaları, 5 milyon \$ dolayından 20 milyon \$ dolayına yükselmiştir. Yılda ortalama \% 10,4 artmıştır. Harcama türleri içinde en yüksek artış, yatırım harcamalarında gerçekleşmiştir. Bu durum, okulöncesi eğitimin yaygınlaştırılması çabalarının bir göstergesidir. Nitekim Türkiye'de eğitim tür ve düzeyleri içinde en az gelişmiş olan okulöncesi eğitimdir. Okulöncesi eğitime yönelik istemin karşılanabilmesi, yatırım harcamalarının hızla artırılmasını gerektirmiştir. Ancak yatırım 
harcamaları 1990-1996 döneminde oldukça hızlı artmışken, izleyen yıllarda ise oldukça hızlı düşmüştür. $\mathrm{Bu}$ düşüşün nedenlerinden biri, 1997 yılında zorunlu eğitim süresinin beş y1ldan sekiz yıla çıkarılması ve \% 100 okullaşma oranına ulaşılmasının hedeflenmiş olmasıdır. 1997 ve 1998 yıllarında ilköğretim yatırımlarına verilen öncelik, okulöncesi eğitim yatırımlarında azalmaya neden olmuştur.

Yatırım harcamalarındaki bu düşüş, öğrenci artışına uygun okul yapılmadığını ve eğitimin kalabalık dersliklerde yapıldığını, ikili eğitimden (sabahçı-öğleci) normal eğitime geçilemediğini göstermektedir. Nitekim 2002-2003 öğretim y1lında derslik başına ortalama öğrenci sayıs1, gelişmiş OECD ülkelerinde 16 iken, Türkiye'de 22'dir.

Okulöncesi eğitim harcamaları içinde, gerek miktar, gerek artış oranı itibariyle en düşük olan, transfer harcamalarıdır. 1990-2002 döneminde okulöncesi eğitimde, transfer harcamaları 2 milyon $\$$ dolayından 0,5 milyon $\$$ dolayına düşmüştür. Yılda ortalama \% 6,7 azalmıştır. Bunun başlıca nedeni, transfer harcamalarının özellikle öğrenci pansiyonları, burslar vb hizmetlere yönelik olması ve okulöncesi eğitimde böyle bir hizmetin olmamasıdır.

Okulöncesi eğitim göstergelerinin 1990-2002 dönemindeki yıllık ortalama artış oranları (\%) Tablo 14’te görülmektedir.

Tablo 14. Okulöncesi Eğitim Göstergelerinin 1990-2002 Dönemindeki Yıllık Ortalama Artış Oranı

\begin{tabular}{|c|c|c|c|}
\hline Gösterge & Artış Oranı $(\%)$ & Gösterge & Artış Oranı (\%) \\
\hline Çăg Nüfusu & 0,2 & $\overline{\text { Okul/Sinıf Sayısı }}$ & 8,2 \\
\hline Öğrenci Sayısı & 7,1 & Köy & 9,7 \\
\hline $\mathrm{K} 1 \mathrm{z}$ & 7,1 & Şehir & 7,6 \\
\hline Erkek & 7,0 & Toplam Harcama (\$) & 6,1 \\
\hline Köy & 7,7 & Cari & 5,8 \\
\hline Şehir & 6,9 & Yatırım & 10,4 \\
\hline Öğretmen Sayıs1 & 5,2 & Transfer & $-6,7$ \\
\hline Kadın & 5,0 & Öğrenci Başına Harcama (\$) & $-1,3$ \\
\hline Erkek & 24.1 & & \\
\hline
\end{tabular}

Kaynak: Milli Eğitim Bakanlığı, Maliye Bakanlığı ve Türkiye İstatistik Kurumu verileri kullanılarak yazar tarafindan hazırlanmıştır.

\section{Tartışma ve Sonuç}

Yaşam düzeyini yükseltmek isteyen her toplumun temel hedefi, varolan kaynaklarını en öncelikli ve en uygun alanlarda kullanmak ve üretim düzeyini en yükseğe çıkarmaktır.

OECD ülkelerinde olduğu gibi Türkiye'de de çok çocuk yerine, nitelikli eğitimle yetiştirilmiş az çocuk tercih edilmektedir. Okulöncesi eğitim çağındaki çocuk nüfusu hemen hemen hiç artmamaktadır. $\mathrm{Bu}$ durumun, yaşanılan çağın koşullarından kaynaklandığı söylenebilir.

Türkiye'de okulöncesi eğitime yönelik toplumsal istem hızla artmıştır. Bu artış, ailelerin giderek bilinçlendiğinin, daha az çocuk sahibi olmakla birlikte daha çok nitelik istediklerinin göstergesidir. Örneğin, Türkiye'de kadın başına ortalama çocuk sayısı 1980 yılında 3,4 iken 2002 yılında 2,5'e düşmüştür. 23 yaşında sahip olunacak iyi bir mesleğin temellerinin, 3 yaşında başlayan nitelikli bir eğitimle atıldığı artık ailelerce bilinmektedir. Sosyo-ekonomik düzeyi 
yüksek meslek ve yaşam sahibi olmayı, yalnızca okulöncesi eğitime bağlamak doğru değildir. Çocukların bilişsel, duyuşsal ve devinişsel özellikleri de önemlidir. Ancak bu özellikleri tetikleyen kaynaklardan belki de en önemlisi okulöncesi eğitimdir.

Türkiye'de yılda ortalama, okulöncesi eğitim okullaşma oranı $\% 0.3$, öğretmen sayısı $\%$ 5.2 , okul/sınıf sayıs1 \% 8.2, öğrenci sayısı \% 7.1 artmış, öğrenci başına yapılan harcama ise \% 1.3 azalmıştır. Diğer bir deyişle harcama dışındaki göstergelerin tümünde artış gerçekleşmiştir.

Türkiye'de son yıllarda başlayan okulöncesi eğitimi yaygınlaştırma çabalarına, OECD ülkeleri çok önceden başlamışlardır. Bu konuda Türkiye, OECD ülkelerinden yaklaşık 40 yıl geride kalmıştır. Ancak Türkiye'deki eğitim nüfusu ve eğitim bütçesi dikkate alındığında çok da karamsar olmamak gerekir. Çünkü Türkiye zorunlu eğitim sorununu bile hala çözememiştir. Yükseköğretim önüne yığılan ortaöğretim mezunları da ayrı bir sorundur. Diğer bir deyişle eğitim tür ve düzeyleri içinde okulöncesi eğitime ancak sıra gelmiştir denilebilir. Türkiye'de okulöncesi eğitimin az yaygınlaşmasının nedenlerinden biri de kadınların işgücü piyasasına katılım oranının düşük olmasıdır. Gelişmiş OECD ülkeleri ile karşılaştırıldığında, Türk kadınının işgücü piyasasına katılımı oldukça düşüktür. Nitekim Türkiye'deki ev kadını sayısı 12 milyon dolayındadır.

Türkiye'de 1981 yılında toplanan 10. Millî Eğitim Şûrası'nda, 2002 yılına kadar 5 yaşındaki nüfusun \% 50'sine okulöncesi eğitim verilmesi ve 2002 yılından sonra da 3-5 yaş grubundaki nüfus için okulöncesi eğitimin zorunlu olması hedeflenmiştir. Ancak anılan hedeflere ulaşılamamıştır. Daha sonraki milli eğitim şuralarında da benzer hedefler yer almış, ancak ulaşılamamıştır.

Milli eğitim şûralarında olduğu gibi, kalkınma planlarında da okulöncesi eğitime ilişkin hedefler yer almaktadır. Nitekim kalkınma planlarında okulöncesi eğitimde \% 7 okullaşma oranına 1990-1991 öğretim yılında, \% 25 okullaşma oranına 2004-2005 öğretim yılında ulaşılması hedeflenmiştir (DPT 1989, s.291 ve 2000, s.83). Ancak bu hedeflerin de hiçbirine ulaşılamamıştır. Ulaşılamama nedenlerinden biri, okullaşma oranında \% 257 artış beklenmesi, buna karşın tüm eğitim harcamaları içinde okulöncesi eğitim harcamalarının \% 175 artmış olmasıdır. Diğer bir deyişle kalkınma planlarındaki hedefler ile eğitim harcamaları arasında bir paralellik sağlanamamıştır.

Türkiye'de okulöncesi eğitim için harcanan parasal kaynaklar, OECD ülkelerinden oldukça azdır. Öğrenci başına yılda ortalama, Türkiye'de 1.000 \$, OECD ülkelerinde ise 5.000 \$ harcanmaktadır. Diğer bir deyişle, OECD ülkelerinin öğrenci başına yaptığı harcama, Türkiye'nin yaptığı harcamanın ortalama 5 katıdır. 1990-2002 dönemindeki eğilim aynen sürerse Türkiye, OECD ülkeleri düzeyine ancak 2040 yılında ulaşabilecektir.

Türkiye'de öğrenci sayısı en az olan ve en az harcama yapılan eğitim türü, okulöncesi eğitimdir. Tüm kamu eğitim harcamalarının ortalama \% 1,2'si okulöncesi eğitime yapılmaktadır.

Okulöncesi eğitim harcamaları yılda ortalama \% 6,1 artmaktadır. Bu oran; cari harcamalarda \% 5.8, yatırım harcamalarında \% 10.4, transfer harcamalarında \% - 6,7'dir. Harcama türleri içinde en yüksek artış oranının yatırımlarda gerçekleşmesi, okulöncesi eğitimin yaygınlaştırılması çabalarının bir göstergesi olarak kabul edilebilir. 
Ekonomik krizlerin yaşandığı yıllarda okulöncesi eğitim harcamaları azalmıştır. Şöyle ki, 1994 yılında okulöncesi eğitim öğrencileri \% 3,3 artmasına karşın, harcamalar \% 29,6 azalmıştır. 1999 yılında öğrenci sayısı \% 4,0 artmasına karşın, harcamalar \% 21, 4 azalmıştır. Benzer biçimde 2001 yılında öğrenci sayısı \% 11,5 artmasına karşın, harcamalar \% 9,4 azalmıştır. Dolayısıyla Türkiye'de yaşanan ekonomik kriz dönemlerinde, bütçesi azaltılan sektörlerin başında eğitim gelmektedir.

Okulöncesi eğitim, gelişmiş OECD ülkelerinde olduğu gibi Türkiye'de de yaygınlaştırılmalı ve toplumun her kesimini kapsayacak bir yapıya kavuşturulmalıdır. Bunun gerçekleşmesi için;

- Merkezi yönetim bütçesinden okulöncesi eğitime ayrılan bütçe artırılmalıdır.

- Öğrenci başına yapılan harcamalar artırılmalıdır.

- Okulöncesi eğitim bütçesinin planlanmasında birinci ölçüt, öğrenci sayısı olmalıdır. Gelecek yılın bütçe planlaması, bu yıl öğrenci başına yapılan harcamadan daha az olmamak koşuluyla yapılmalıdır. İkinci ölçüt, çağdaş fiziksel donanım olmalıdır.

Ancak bu çalışma 1990-2002 dönemini kapsadığ i için, 2002 yılından sonraki harcamalara yönelik yapılan değişikliklerin dikkate alınması gerekmektedir. O nedenle 20032019 dönemini kapsayan harcamaların çözümlenmesi, uzun dönemli eğitim planlarının yapılmasına katkı sağlayabilir. 


\section{Kaynakça}

Âdem, M. (1993), Ulusal eğitim politikamız ve finansmanı, Ankara: Ankara Üniversitesi, Eğitim Bilimleri Fakültesi Yayını.

Aksoy, H. H. (2014), Eleştirel eğitim deneyimleri üstüne düşünmek, Eleştirel Pedagoji Dergisi, 42, 2426.

Anne-Çocuk Eğitim Vakfi (AÇEV), (2005), Erken Müdahalenin Erişkinlikte Süren Etkileri, İstanbul.

Devlet Planlama Teşkilatı (DPT), (1989), Altıncı kalkınma planı (1990-1994), Ankara.

DPT (2000), Sekizinci kalkınma planı (2001-2005), Ankara.

DPT (2007), Ekonomik ve sosyal göstergeler (1950-2006), Ankara.

Education Information Network in European (EURYDICE), (2005), Avrupa'da eğitime ilişkin temel veriler-2005, Lüksemburg.

EURYDICE (2009), Avrupa'da ĕgitime ilişkin önemli veriler (2009), Ankara: Du\&Se Ajans.

Milli Eğitim Bakanlığı (MEB), (1981), Onuncu milli ĕgitim şurası, Ankara: Milli Eğitim Basımevi.

MEB, Okulöncesi ĕgitim kurumlarl yönetmeliği (OÖEKY), Resmi Gazete: 27.10.2007 - 26683.

MEB, Okulöncesi Eğitim Genel Müdürlüğü Web Sitesi (www.ooegm.meb.gov.tr).

MEB, Bütçe kesin hesapları. Bütçe Dairesi Başkanlığı.

MEB ve UNICEF (2013), Toplum temelli erken çocukluk hizmetleri sunumu kllavuzu, UNICEF Türkiye Ofisi, Ankara.

Organization for Economic Co-operation and Development (OECD), (1995), OECD education statistics (1985-1992), Paris.

OECD (1995), Education at a Glance-OECD Indicators 1993, Paris.

OECD (2000), Education at a Glance-OECD Indicators 1998, Paris.

OECD (2006), Society at a glance: OECD social indicators - 2006 edition, Paris.

OECD (2006), Education at a glance-summary, Paris.

OECD (2007), Education at a glance-OECD indicators 2007, Paris.

OECD (2007/b), OECD in figures-2007, Paris.

OECD, http://stats.oecd.org/wbos/Index.aspx? (30 May1s 2008).

OECD (2008), Education at a glance-OECD indicators 2008, Paris.

Sönmez V. ve Alacapınar F.G. (2011), Örneklendirilmiş bilimsel araştırma yöntemleri, Anı Yayıncılık, Ankara.

Tuzcu, G. (2006), Avrupa Birliği’ne giriş süreci ve ĕgitimde vizyon 2023, Ankara: Türk Eğitim Derneği (TED) Yayını.

Türkiye İstatistik Kurumu (TÜİK) / Devlet İstatistik Enstitüsü (DİE), 1990 genel nüfus sayımı, Ankara.

TÜİK (1990-2002), Milli eğitim istatistikleri - örgün eğitim, Ankara.

TÜİK 2001-2010 nüfus projeksiyonlarl (Yayınlanmamış veriler).

TÜİK (2005), Türkiye eğitim harcamaları araştırması-2002, Ankara.

United National Educational, Scientific and Cultural Organization (UNESCO), (2002), EFA global monitoring report 2002 (www.unesco.org). Paris: UNESCO Publish.

UNESCO (2007), Education for all 2007 (www.unesco.org), (09.05.2009). 


\section{Extended Abstract}

\section{Introduction}

In the current study, number of schools-teachers-students, schooling rates, and expenditures of preschool education in Turkey were analyzed. The findings were compared to the analyses of OECD countries. The research covers a period of 13 years (1990-2002).

The amount of financial resources spent on preschool education indicates the importance given to preschool education in the whole educational system. The analysis of financial resources contributes to the determination of whether the objectives of the education have been achieved and the findings help develop rational policies.

\section{Methodology}

The current study is a combination of quantitative and descriptive research carried out through "survey research" model (document analysis). All preschool institutions in Turkey for children between the ages 3 to 5 were examined.

In the 13-year period, comprising of data collected between 1990 to 2002, increases / decreases in the number of schools-teachers-students, schooling rates and educational expenditures were calculated by "linear (semi-logarithmic) pattern" and basic arithmetic methods.

The study was concluded in the 2002-2003 educational year due to the change in the budget system in Turkey by the end of 2003 (the budgeting system changed from program budgeting to analytical budgeting system). The data of the current study were gathered by reviewing the national and international literature on the topic.

\section{Findings}

In the 13-year period between 1990 to 2002 in Turkey, the annual average schooling rate increased by $0.3 \%$, the number of teachers increased by $5.2 \%$, the number of schools / classes increased by $8.2 \%$ and the number of students increased by $7.1 \%$. However, expenditure per student has declined by $1.3 \%$. In other words, the increase in the number of schools-teachersstudents and schooling rate is not proportionate with the increase in the amount of expenditure.

Schooling rate in the $1990-2002$ period increased to $86.9 \%$ from $66.5 \%$ in OECD countries while it increased to $6.7 \%$ from $2.9 \%$ in Turkey. The predictions indicate that if the same growth rate continues steadily in Turkey, the schooling rate will be able to reach the schooling rate of the year 2002 in OECD countries by the year $2040(\% 86,9)$.

Social demand for preschool education in Turkey has been increasing every year. This increase shows that parents are becoming more conscious and they are giving more importance to the quality of a child rather than the number of children. The increase in the social demand naturally brings about an increase in the demand for school buildings, equipment, teachers and budget as well.

Although the number of students is increasing rapidly in Turkey, this number is still far behind the OECD countries. Turkey has remained rather late in giving importance to preschool education and in expanding preschool education. For example, in the 2002-2003 academic year, the average number of students in OECD countries is six times more than the number of 
students in Turkey. While the number of preschool students accounts for $10 \%$ of all formal education students in OECD countries, it constitutes only $2 \%$ in Turkey.

In Turkey, preschool education has the least number of students compared to overall students in the education system and therefore the expenditure on preschool education is comparably the lowest. Expenditure per student (US \$) decreased by $1.3 \%$ on average each year and the number of students increased by $7.1 \%$ on average each year. In other words, there has been no corresponding expenditure with the number of student growth. This shows that educational financing and expenditure planning have not been carried out based upon scientific data.

\section{Discussion}

It is of great importance to investigate the evolution of educational expenditures in order to develop more realistic and applicable policies and to distribute the resources most appropriately and efficiently.

Efforts to expand preschool education has started in OECD countries much earlier compared to Turkey. In Turkey these efforts started only in the past couple of years. In this regard, Turkey has fallen nearly 40 years behind the OECD countries. However, considering the education population and education budget in Turkey, there is no need to be too pessimistic mainly because Turkey has not solved the problems of compulsory primary education completely yet. Furthermore, secondary education graduates waiting for higher education is a separate problem. In other words, it can be concluded that only recently preschool education has been prioritized among the education types in Turkey.

In a research carried out by Turkey Statistical Institute (TSI) in the 2002-2003 academic year, it was found that on average $\$ 102$ was spent per student in public schools. However, in the current study, it was found that $\$ 407$ was spent per student. The fact that there is such a great difference between these two studies is quite remarkable. One reason for this difference might be attributed to the fact that the research carried out by TSI was conducted on a sample but the current study was done with the whole population.

Preschool education should be expanded in Turkey just like it is in OECD countries and it should be expanded to include the whole society. In order to achieve this;

- The allocated budget for preschool education from the central administration budget should be increased,

- The expenditures per student should be increased,

- Primary criterion for the education budgeting planning should be the number of students. Budget planning for the following year should be done on the principle that it should not be less than the budget per student the present year. Second criterion should be providing modern physical environments.

However, since this study focused only on the period from 1990 to 2002, there is need to consider the changes made after 2002 in regard to expenditures. Therefore, studies focusing on expenditures allocated per student in the period from 2003 to 2019 can contribute to the efforts of making long-term education planning. 